\title{
Effect of Antimalarial Drugs on the Bioavailability of the Methylenediphosphonic Acid Labeled with Technetium99m (99mTc-MDP) in Wistar Rats
}

\author{
Cecília Maria de Carvalho Xavier Holanda ${ }^{1 *}$, Rodrigo de Carvalho Holanda Leite ${ }^{2}$, \\ Reginauro Alves da Silva Nunes', Harina Alves de Oliveira ${ }^{2}$, Maria Teresa Jansen de \\ Almeida Catanho ${ }^{3}$, Grace Mary Lima de Souza ${ }^{3}$ and Mário Bernardo-Filho ${ }^{4}$ \\ ${ }^{1}$ Universidade Federal do Rio Grande do Norte - UFRN; Departamento de Microbiologia e Parasitologia; \\ Programa de Pós-Graduação em Ciências da Saúde; Av. Salgado Filho, 3000;59078-970; cechol@ufrnet.br; Natal \\ - RN - Brasil. ${ }^{2}$ Hospital Universitário Onofre Lopes - HUOL; Av. Nilo Peçanha, 620; 59012-300; Natal - RN - \\ Brasil. ${ }^{3}$ Universidade Federal de Pernambuco - UFPE; Departamento de Biofísica e Radiobiologia; R. Moraes \\ Rego, s/n; 50670-420; Recife - PE - Brasil. ${ }^{4}$ Universidade do Estado do Rio de Janeiro; Instituto de Biologia \\ Roberto Alcântara Gomes; Departamento de Biofísica e Biometria; Av. 28 de Setembro, 87; 20551-030; Rio de \\ Janeiro - RJ - Brasil
}

\begin{abstract}
The aim of this work was to study the effect of antimalarial drugs on the bioavailability of ${ }^{99 m}$ Tc-MDP in rats. Mefloquine $(M Q)$ and artemisinin $(A M)$ were administered in two treated groups $(T)$ and sorbitol in control group (C) for 7 days. Then, ${ }^{99 m}$ Tc-MDP was injected in all groups and \%ATI was calculated. A significant increase of $\% A T I$ in $M Q$ group, from $C$ to $T$, occurred in spleen $(0.35 \pm 0.10$ to $0.58 \pm 0.13)$, liver $(1.69 \pm 0.28$ to $3.31 \pm 0.07)$ and blood (0.79 \pm 0.17 to2.09 \pm 0.53$)$. The \%ATI increased significantly in AM group:femur $(2.76 \pm 0.59$ to5.98 \pm 0.70$)$, liver (1.69 \pm 0.28 to $4.59 \pm 0.68)$, lungs $(0.29 \pm 0.05$ to6.22 \pm 0.86$)$, spleen $(0.35 \pm 0.10$ to $0.86 \pm 0.15)$ and blood $(0.79 \pm 0.17$ to4.65 \pm 0.74$)$. A significant decrease of \%ATI occurred in MQ group:bladder $(0.75 \pm 0.07$ to0.26 \pm 0.05$)$, stout bowel (2.13 \pm 0.34 to $0.66 \pm 0.19)$, pancreas $(0.87 \pm 0.24$ to $0.28 \pm 0.18)$, kidneys $(7.00 \pm 1.52$ to $3.46 \pm 0.62)$, brain $(0.27 \pm 0.08$ to $0.05 \pm 0.01)$ and also in AM group:bladder $(0.75 \pm 0.07$ to0.30 \pm 0.05$)$, stout bowel $(2.13 \pm 0.34$ to $0.36 \pm 0.08)$, muscle (2.04 \pm 0.39 to $0.26 \pm 0.06)$, pancreas $(0.87 \pm 0.24$ to0.46 \pm 0.12$)$ and kidneys $(7.00 \pm 1.52$ to $4.35 \pm 0.28)$. These results could be associated to biological effects of antimalarial drugs.
\end{abstract}

Key words: Drug interaction, radiopharmaceuticals, ${ }^{99 \mathrm{~m}} \mathrm{Tc}-\mathrm{MDP}$, antimalarial drugs, mefloquine, artemisinin

\section{INTRODUCTION}

Malaria, once a target for eradication, remains a major threat for human health, especially in subSaharan Africa. An estimated 300-500 million clinical cases occur each year, and between one and three million deaths, primarily of children and pregnant women, are attributable to this disease.
Every 40 seconds a child dies of malaria, resulting in a daily loss of more than 2000 young lives worldwide. These estimates render malaria the pre-eminent tropical parasitic disease and one of the top three killers among communicable diseases (Miller et al., 2002; Sachs and Malaney, 2002).

Plasmodium falciparum, one of the four malarial parasite species infecting humans, is the most

* Author for correspondence 
lethal Plasmodia and still a major cause of the disease burden and mortality in malaria endemic areas. Due to the wide spread drug resistance in combination with poor socio-economic situation in the vast majority of the endemic countries, malaria is today a great global challenge. The efforts to find a suitable drug is, however, progressing (Bremen, 2001; Miller et al., 2002). Mefloquine and artemisinin are both in the top of the best drugs used in the treatment and prophylaxis of falciparum malaria multidrug resistant. Mefloquine is active against all forms of malaria parasites including chloroquine or multidrug resistant strains of $P$. falciparum. It is indicated in severe malaria including cerebral malaria, and it ensures both suppression and cure of infections with multidrug resistant $P$. falciparum. It has no effect on gametocytes of $P$. falciparum and it does not eliminate exoerythrocytic (intrahepatic) stages of P. vivax (Schwartz et al., 2001). The exact mechanism of action of mefloquine is unknown. It has schizontocidal activity - due to destruction of asexual erythrocyte forms of $P$. falciparum and $P$. vivax.

However parasite resistance to the actual antimalarial drugs has already reached alarmingly high levels in Southeast Asia and in the African continent, and, therefore, there is a dire need for new drugs in the prophylaxis and treatment of malaria (WHO, 2000). Artemisinin, an ancient Chinese herbal remedy, represents a new class of antimalarials that is effective against drug-resistant $P$. falciparum strains. Chinese researchers isolated artemisinin or qinghaosu in 1972 from Artemisia annua, L. (Klayman et al., 1985). This plant has been used in traditional Chinese medicine as a remedy for chills and fevers for more than 2000 years. The drug is present in the leaves and flowers of the plant (van Agtmael et al., 1999). Western interest in this agent began to grow when multidrug resistant $P$. falciparum strains began to spread, especially in Southeast Asia. Many derivatives have been synthesized from dihydroartemisinin, and out of these, artemether, arteether, artesunic acid and artelinic acid are either currently in use or being evaluated for use.

The advent of Technetium-99m (99mTc) provided the first convenient radionuclide for labeling a variety of molecules and cells used as radiopharmaceuticals. Its wide use in nuclear medicine is due to its optimal physical characteristics (half-life of $6 \mathrm{~h}$, gamma ray energy of $140 \mathrm{KeV}$ and resulting minimal dose to the patient), convenient availability from a ${ }^{99} \mathrm{Mo} /{ }^{99 \mathrm{~m}} \mathrm{Tc}$ generator, and negligible environmental impact (Early and Sodee, 1995; Saha, 1998). In nuclear medicine, these radiopharmaceuticals are employed in the study of blood flow, metabolism, morphology of an organ and to evaluate the drug formulation and drug delivery systems (Chandra, 1998; Perkins and Frier, 1999). According to Hesselewood and Leung (1994), Owunwanne and Collaborators (1995) and Saha (1998), one of these radiopharmaceuticals is the well known methylenediphosphonic acid labeled with ${ }^{99 \mathrm{~m}} \mathrm{Tc}$ $\left({ }^{99 \mathrm{~m}} \mathrm{Tc}-\mathrm{MDP}\right)$, which is used to perform bone scintigraphy (Owunwanne et al., 1995; Saha, 1998). The ${ }^{99 \mathrm{~m}} \mathrm{Tc}-\mathrm{MDP}$ has been used for bone scanning and for the localization of primary bone tumours, metastatic tumours and metabolic bone diseases.

Many authors have been studying the drug interaction as an important factor that can alter the behavior of the radiopharmaceuticals in different organs and tissues of the animal models (Owunwanne et al., 1998; Mattos et al., 1999; Xavier Holanda et al., 2002; Amorim et al., 2003; Britto et al. 2004; Jales-Jr. et al., 2004). Frequently, this phenomenon is responsible for modification of the bioavailability of the radiopharmaceutical (Owunwanne et al., 1995; Hung et al., 1996; Xavier Holanda et al., 2002; Gomes et al., 2002).

Thus, the nuclear medicine practices have increased continually in recent decades. This modality is chosen for its diagnostic qualities and appears to be advantageous in delivering low radiation doses to patients. The evidence that natural and synthetic drug can affect radiolabeling or bioavailability of radiopharmaceuticals in setting of nuclear medicine clinic is already known (Saha, 1998; Gomes et al., 2002; Xavier Holanda et al., 2002; Amorim et al., 2003). These interactions can alter results of nuclear medicine procedures in a patient under chemotherapeutic treatment due to a concomitant disease. This fact may conduce a misdiagnosis or unnecessary exposure to radiation during the repetition of these exams.

The aim of this study was to evaluate the influence of natural and synthetic antimalarial drugs (artemisinin and mefloquine, respectively) on the bioavailability of the radiopharmaceutical methylenediphosphonic acid labeled with technetium ${ }^{-99}$ m (99mTc-MDP) in Wistar rats. 


\section{MATERIAL AND METHODS}

The animals weighing on average $230 \mathrm{~g}$, obtained from Biotério do Centro de Ciências da Saúde of Universidade Federal do Rio Grande do Norte, Natal - RN, Brazil, were housed in groups with free access to water and food. Twenty-four animals were used in this experiment and were randomly divided into three groups (two treated groups and one control group) of eight animals each one.

Experiments were performed according to local regulations for animal experimentation (approved by the Ethical Committee for Using Animals of UFRN) and they were sacrificed rapidly in a chamber with ethyl ether. In the first treated group, cloridrate of mefloquine diluted in sorbitol (50mg/10mL; Linha Medicamentos - Rio de Janeiro, Brazil) was administered orally $(0.8 \mathrm{~mL} / \mathrm{kg} /$ day $)$ into male Wistar rats $(\mathrm{n}=8 ; 3$ month-old-age), in single dose during 7 days. In the second treated group, Artemisia vulgaris $L$. (prepared from a $10 \%$ dye-mother solution and diluted in sorbitol, Laboratório Herbarium - Rio de Janeiro, Brazil) was also administered orally $(0.4 \mathrm{~mL} / 100 \mathrm{~g} / \mathrm{day})$ into male Wistar rats $(\mathrm{n}=8 ; 3$ month-old-age), in single dose during 7 days. One hour after the last dose was injected, via ocular plexus, $0.1 \mathrm{~mL}$ of the ${ }^{99 \mathrm{~m}} \mathrm{Tc}-\mathrm{MDP}$ (3.7MBq). The control group $(\mathrm{n}=8 ; 3$ month-old-age) received $0.8 \mathrm{~mL} / \mathrm{kg} / \mathrm{day}$ of the sorbitol solution same way, and also received $0.1 \mathrm{~mL}$ of the ${ }^{99 \mathrm{~m}} \mathrm{Tc}-\mathrm{MDP}$ one hour after the last dose of the sorbitol solution.

To prepare the ${ }^{99 \mathrm{~m}} \mathrm{Tc}-\mathrm{MDP}$, ${ }^{99 \mathrm{~m}} \mathrm{Tc}$, as sodium pertechnetate, freshly prepared from a ${ }^{99} \mathrm{Mo} /{ }^{99 \mathrm{~m}} \mathrm{Tc}$ generator (Instituto de Pesquisas Energéticas e Nucleares, Brazil), was added to a kit of MDP (Liga Norteriograndense Contra o Cancer, Brazil). Each group of 8 rats was quickly sacrificed $60 \mathrm{~min}$ after injection of the ${ }^{99 \mathrm{~m}} \mathrm{Tc}-\mathrm{MDP}$. Various organs from the animals were isolated (brain, heart, thyroid, lungs, kidneys, testis, stomach, intestines, pancreas, spleen, liver, abdominal muscle, femur, bladder and a sample of blood) and were put in vials and the radioactivity of the ${ }^{99 \mathrm{~m}} \mathrm{Tc}-\mathrm{MDP}$ was counted in a counter NaI (TI), Automatic Gamma Counter-1272, Clinigamma, LKB, Wallac, Finland. The percentages of total radioactivity (\%ATI) in the organs were calculated dividing the activity in each organ by the total activity administered. The results were compared with the control group and statistical analyses were performed by Mann-Whitney U test $(p<0.01)$.

\section{RESULTS}

Table 1 shows the relationship between the uptake (\%ATI) of the ${ }^{99 \mathrm{~m}} \mathrm{Tc}-\mathrm{MDP}$ in the group that was treated with mefloquine $(n=8)$ and in the control group $(n=8)$, sixty minutes after administered the ${ }^{99 \mathrm{~m}} \mathrm{Tc}-\mathrm{MDP}$. The analysis of the results showed a significant $(p<0.01)$ increase in the uptake of radioactivity in spleen, liver, muscle and blood. A significant decrease $(p<0.01)$ in the \%ATI of ${ }^{99 \mathrm{~m}} \mathrm{Tc}-\mathrm{MDP}$ occurred in bladder, brain, heart, pancreas, kidneys, stout bowel and stomach. The results also revealed no significant alteration of the \%ATI in testis, thyroid, lungs, femur and thin bowel.

Table 2 shows the relationship between the uptake (\%ATI) of the ${ }^{99 \mathrm{~m}} \mathrm{Tc}-\mathrm{MDP}$ in the group that was treated with artemisinin $(n=8)$ and in the control group $(n=8)$, sixty minutes after administration of the ${ }^{99 \mathrm{~m}} \mathrm{Tc}-\mathrm{MDP}$. The analysis of the results showed a significant $(p<0.01)$ increase in the uptake of radioactivity in spleen, brain, femur, liver, lungs and blood. A significant decrease $(p<0.01)$ in the $\%$ ATI of the ${ }^{99 \mathrm{~m}} \mathrm{Tc}$ - MDP was observed in bladder, heart, thin bowel, stout bowel, abdominal muscle, pancreas, kidneys and testis. There was no significant alteration in the \%ATI in thyroid and stomach. 
Table 1 - Effect of mefloquine on the bioavailability of the ${ }^{99 \mathrm{~m}}$ Tc-MDP activity in Wistar rats, after 60 min administered the ${ }^{99 \mathrm{~m}}$ Tc-MDP.

\begin{tabular}{l|cc|cc}
\hline \multirow{2}{*}{ Organs } & \multicolumn{3}{c}{ \% ATI } & \multicolumn{2}{c}{ Treated } \\
\cline { 2 - 5 } Abdominal muscle & \multicolumn{2}{c}{ Control } & 3.539 & \pm 0.874 \\
Bladder & 2.047 & \pm 0.397 & 0.266 & \pm 0.056 \\
Blood & 0.752 & \pm 0.076 & 2.098 & \pm 0.535 \\
Brain & 0.799 & \pm 0.178 & 0.050 & \pm 0.016 \\
Femur & 0.279 & \pm 0.081 & 3.690 & \pm 1.186 \\
Heart & 2.769 & \pm 0.598 & 0.662 & \pm 0.192 \\
Kidneys & 1.106 & \pm 0.072 & 3.465 & \pm 0.620 \\
Liver & 7.007 & \pm 1.523 & 3.310 & \pm 0.079 \\
Lungs & 1.697 & \pm 0.281 & 0.204 & \pm 0.047 \\
Pancreas & 0.294 & \pm 0.057 & 0.288 & \pm 0.183 \\
Spleen & 0.871 & \pm 0.244 & 0.584 & \pm 0.134 \\
Stomach & 0.353 & \pm 0.103 & 3.886 & \pm 0.851 \\
Stout Bowel & 6.987 & \pm 0.980 & 0.668 & \pm 0.193 \\
Testis & 2.131 & \pm 0.341 & 0.268 & \pm 0.084 \\
Thin Bowel & 0.497 & \pm 0.082 & 2.848 & \pm 0.892 \\
Thyroid & 2.055 & \pm 0.537 & 2.042 & \pm 0.422 \\
\hline
\end{tabular}

Table 2 - Effect of artemisinin on the bioavailability of the ${ }^{99 \mathrm{~m}} \mathrm{Tc}-\mathrm{MDP}$ activity in Wistar rats, after 60 min administered the ${ }^{99 \mathrm{~m}} \mathrm{Tc}-\mathrm{MDP}$.

\begin{tabular}{l|cc|cc}
\hline \multirow{2}{*}{ Organs } & \multicolumn{3}{c}{ \% ATI } \\
\cline { 2 - 5 } Control & \pm 0.397 & 0.265 & Treated \\
\hline Abdominal muscle & 2.047 & \pm 0.076 & 0.303 & \pm 0.053 \\
Bladder & 0.752 & \pm 0.178 & 4.656 & \pm 0.743 \\
Blood & 0.799 & \pm 0.081 & 0.509 & \pm 0.071 \\
Brain & 0.279 & \pm 0.598 & 5.988 & \pm 0.701 \\
Femur & 2.769 & \pm 0.141 \\
Heart & 1.106 & \pm 0.072 & 0.470 & \pm 0.141 \\
Kidneys & 7.007 & \pm 1.523 & 4.352 & \pm 0.285 \\
Liver & 1.697 & \pm 0.281 & 4.599 & \pm 0.684 \\
Lungs & 0.294 & \pm 0.057 & 6.229 & \pm 0.868 \\
Pancreas & 0.871 & \pm 0.244 & 0.469 & \pm 0.122 \\
Spleen & 0.353 & \pm 0.103 & 0.866 & \pm 0.156 \\
Stomach & 6.987 & \pm 0.980 & 7.352 & \pm 0.990 \\
Stout Bowel & 2.131 & \pm 0.341 & 0.367 & \pm 0.080 \\
Testis & 0.497 & \pm 0.082 & 0.194 & \pm 0.041 \\
Thin Bowel & 2.055 & \pm 0.537 & 0.484 & \pm 0.069 \\
Thyroid & 2.555 & \pm 0.664 & 3.093 & \pm 0.694 \\
\hline
\end{tabular}

\section{DISCUSSION}

There is considerable evidence that the biokinetics of radiopharmaceuticals may be altered by a variety of drugs, interaction of drugs (natural or synthetic), radiation therapy, disease states and surgical procedures (Sampson, 1993; Hesselewood and Leung, 1994; Harbert et al., 1996). If unknown, such factors may lead to poor visualization, a requirement to repeat the procedure resulting in unnecessary irradiation of organs or even misdiagnosis (Hojelse et al., 1994; Hung et al., 1996; Saha, 1998). Knowledge of altered bioavailability of the radiopharmaceuticals due to drug interaction definitely helps the physician to avoid misinterpretation of the scintigraphic images and, thus, an incorrect diagnosis and helps to prevent or treat adequately possible adverse reactions to the radiopharmaceuticals (Hladik et al., 1987; 
Sampson, 1993). Some drugs enhance the localization of the radiopharmaceutical in the target organ, while others depress the uptake. In some cases, the bioavailability is shifted to other organs (Hladik et al., 1987; Saha, 1998). In addition, the alteration of the bioavailability of a radiopharmaceutical due to the effect of a drug in a specific tissue could aid in identifying the toxicolologic effect of a substance in an organ.

Many authors have reported that various drugs (natural or synthetic) are capable to alter the bioavailability of radiopharmaceuticals. For example, Chen and Collaborators (1994) have reported that gentamicin could cause abnormal renal uptake to be seen on bone scintigraphy using ${ }^{99 \mathrm{~m}} \mathrm{Tc}-\mathrm{MDP}$ and the presence of the radiopharmaceutical in the kidneys due to its nephrotoxicity. Santos and Collaborators (1995) have demonstrated that cyclophosphamide was capable to alter the effective half-life of the radiopharmaceuticals ${ }^{99 \mathrm{~m}} \mathrm{Tc}-\mathrm{MDP}$ and ${ }^{{ }^{99 \mathrm{~m}} \mathrm{Tc}-}$ pertechnetate. Gomes and Collaborators (1998) have reported that mitomycin-C increased the uptake of the ${ }^{99 \mathrm{~m}} \mathrm{Tc}-\mathrm{MDP}$ in thymus, ovary, uterus, heart, stomach, pancreas, kidneys, spleen and lungs. Cronhjort and Collaborators (1998) have observed that the activity bioavailability of the ${ }^{99 \mathrm{~m}} \mathrm{Tc}-\mathrm{HDP}$ and ${ }^{99 \mathrm{~m}} \mathrm{Tc}-\mathrm{MDP}$ in mice was affected by the phosphate balance and, consequently, could affect the image quality at bone scintigraphy. Mattos and Collaborators (1999) have studied the effect of a chemotherapeutic drug on the bioavailability of the ${ }^{99 \mathrm{~m}} \mathrm{Tc}-\mathrm{MDP}$ in different organs isolated from animals treated with vincristine and have shown a decrease of the uptake in uterus, ovary, spleen, thymus, inguinal and mesenteric lymph nodes, kidney, liver, pancreas, stomach, heart, brain and bone. Xavier Holanda and Collaborators (2002) have demonstrated a significant reduction of the \%ATI in spleen, femur, kidneys and liver isolated from Wistar rats treated with the antileishmanial glucantime on the bioavailability of the ${ }^{99 \mathrm{~m}} \mathrm{Tc}-$ MDP. Amorim and Collaborators (2003) have studied the effect of a natural drug on the bioavailability of the ${ }^{99 \mathrm{~m}} \mathrm{Tc}$ - sodium pertechnetate in various organs isolated from animals treated with Punica granatum and Britto and Collaborators (2004) observed significant increase in liver, kidney, bladder, stomach, thyroid and blood of rats treated with tamoxifen on the bioavailability of the ${ }^{99 \mathrm{~m}} \mathrm{Tc}-\mathrm{MDP}$.
Mefloquine and artemisinin are the most effective drugs in the treatment against parasites of the genus Plasmodium, mainly $P$. falciparum. Mefloquine is distributed extensively over tissues and is predominantly excreted in the bile and faeces. It is highly protein bound (98\%) and may accumulate in erythrocytes (Palmer et al., 1993; Price et al., 1999). It acts on the erythrocytic stage of malarial parasites and it may act by forming toxic complexes with free heme of hemoglobin, which damage membranes of the parasite and interact with other plasmodial components. Mefloquine resistance that leads to treatment failure, results in the preferential transmission of mefloquine-resistant malaria parasites. This accelerates the spread of resistant strains and may increase the incidence of malaria (Price et al., 1999). Thus, the increase in occurrence of drug resistant malaria parasites has necessitated the urgent development of novel antimalarial drugs to control this infection throughout the world. Artemisinin is a promising and a potent antimalarial drug for this. There is increasing acceptance that existing antimalarial drugs should be combined with an artemisinin derivative as protection to the development of resistance (White et al., 1999; White, 2004).

Artemisinin and its derivatives concentrates in parasitized red blood cells (RBCs) and kill all stages of the malaria parasite. For this, it interacts with heme of hemoglobin in RBCs to produce carbon-centered free radicals that alkylate protein and damage the microorganelles and membranes of the parasites (Meshnick and Dobson, 2001).

As mentioned above, the most prominent group of radiopharmaceuticals are the diphosphonates, which are used for scanning the skeleton. Technetium-99m labeled diphosphonates ${ }^{99 \mathrm{~m}} \mathrm{Tc}$ diphosphonates) such as methylenediphosphonic acid (MDP) has been used for bone scanning and for the localization of primary bone tumours, metastatic tumours and metabolic bone diseases. The uptake of the ${ }^{99 \mathrm{~m}} \mathrm{Tc}-\mathrm{MDP}$ in bone reflects bone metabolism and blood flow. The major pathway of elimination of the ${ }^{99 \mathrm{~m}} \mathrm{Tc}$ diphosphonates is through the kidneys (Saha, 1998; Thrall and Ziessman, 2003).

In this study, the increase observed in the \%ATI of the ${ }^{99 \mathrm{~m}}$ Tc-MDP in femur of rats treated with artemisinin probably represented changes induced by this drug at the site of hydroxyapatite crystal or calcium phosphate deposition (Saha, 1998). A significant increase was also observed in the 
\%ATI of the ${ }^{99 \mathrm{~m}} \mathrm{Tc}-\mathrm{MDP}$ in liver of rats treated with artemisinin and mefloquine, which was probably due to metabolization process of these drugs in this organ. A significant decrease in the uptake (\%ATI) of the ${ }^{99 \mathrm{~m}} \mathrm{Tc}-\mathrm{MDP}$ in kidneys, bladder and stout bowel of rats treated was observed with mefloquine and artemisinin, which was possibly due to the fact that their conjugates and metabolites were mainly excreted in the urine and in the faeces, respectively (Meshnick and Dobson, 2001; White, 2003; White, 2004). The metabolization and excretion processes and the metabolites produced probably could contribute to a reduction in the uptake of ${ }^{99 \mathrm{~m}} \mathrm{Tc}-\mathrm{MDP}$ in these organs (kidney, bladder and stout bowel).

In conclusion, the knowledge about the drugs interaction with the radiopharmaceuticals is very important to secure and safe diagnosis, and the development of biological models to study this phenomenon is highly relevant and desired. Furthermore, these determinations are important as if mefloquine and/or artemisinin have also an effect in the organ (dimension and/or density) in human beings, it could be responsible for artifacts that could induce misdiagnosis. The study of the modifications in the uptakes of the radiopharmaceuticals induced by drugs could be an important tool to evaluate the toxic effect of chemicals.

\section{ACKNOWLEDGEMENTS}

The authors thank Programa de Pós-graduação em Ciências da Saúde - UFRN, Laboratório de Cirurgia Experimental - UFRN, Hospital Universitário Onofre Lopes, Departamento de Microbiologia e Parasitologia - UFRN, Departamento de Biofisica e Radiobiologia UFPE, Departamento de Biofisica e Biometria UERJ and Liga Norteriograndense Contra o Câncer - RN for the support.

\section{RESUMO}

Há evidências que algumas drogas usadas para doenças humanas podem modificar a biodisponibilidade de radiofármacos. Nós estudamos o efeito de drogas antimaláricas na biodisponibilidade do ${ }^{99 \mathrm{~m}} \mathrm{Tc}-\mathrm{MDP}$ em ratos. Mefloquina (MQ) e artemisinina (AM) foram administradas em dois grupos tratados (T) e sorbitol no grupo controle (C) por 7 dias. Em seguida, ${ }^{99 \mathrm{~m}} \mathrm{Tc}-\mathrm{MDP}$ foi injetado em todos os grupos e o \%ATI foi calculado. Um aumento significativo do \%ATI no grupo da MQ, do controle para o tratado, ocorreu no baço $(0,35 \pm 0,10$ para $0,58 \pm 0,13)$, fígado $(1,69 \pm 0,28$ para $3,31 \pm 0,07)$ e sangue $(0,79 \pm 0,17$ para $2,09 \pm 0,53)$. O \%ATI aumentou significantemente no grupo da AM: no fêmur $(2,76 \pm 0,59$ para $5,98 \pm 0,70)$, fígado $(1,69 \pm 0,28$ para $4,59 \pm 0,68)$, pulmões $(0,29 \pm 0,05$ para $6,22 \pm 0,86)$, no baço $(0,35 \pm 0,10$ para $0,86 \pm 0,15)$ e sangue $(0,79 \pm 0,17$ para 4,65 $\pm 0,74)$. Uma significante diminuição do \%ATI ocorreu no grupo da MQ: na bexiga $(0,75 \pm 0,07$ para $0,26 \pm 0,05)$, intestino grosso $(2,13 \pm 0,34$ para $0,66 \pm 0,19)$, pâncreas $(0,87 \pm 0,24$ para $0,28 \pm 0,18)$, rins $(7,00 \pm 1,52$ para $3,46 \pm 0,62)$, cérebro $(0,27 \pm 0,08$ para $0,05 \pm 0,01)$ e, também, no grupo da AM: bexiga $(0,75 \pm 0,07$ para $0,30 \pm 0,05)$, intestino grosso $(2,13 \pm 0,34$ para $0,36 \pm 0,08)$, músculo $(2,04 \pm 0,39$ para $0,26 \pm 0,06)$, pâncreas $(0,87 \pm 0,24$ para $0,46 \pm 0,12)$ e rins $(7,00 \pm 1,52$ para $4,35 \pm 0,28)$. Estes resultados podem estar associados aos efeitos biológicos das drogas antimaláricas.

\section{REFERENCES}

Amorim, L. F.; Xavier Holanda, C. M. C.; Catanho, M. T.; Terra, D. A.; Brandão, K. C.; Jales-Jr., L. H.; Britto, L. M. L.; Gomes, M. L.; Melo, V. G.; Bernardo-Filho, M. and Jales, R. L. C. L. (2003), Assessment of the effect of Punica granatum (pomegranata) on the bioavailability of the radiopharmaceutical sodium pertechnetate $(99 \mathrm{mTc})$ in Wistar rats. Cell. Mol. Biol., 49 : (4), 501-7.

Bremen, J. (2001), The ears of the hippopotamus: manifestations, determinants, and estimates of the malaria burden. Am. J. Trop. Med. Hyg., 64 : (1/2), 1-11.

Britto, L. M. L.; Xavier Holanda, C. M. C.; Jales, R. L. C.; Marques, F. M. H.; Jales-Jr., L. H.; Brandão, K. C.; Amorim, L. F. and Bernardo-Filho, M. (2004), Effects of tamoxifen on the kinetic of biodistribution of radiopharmaceuticals in Wistar rats. J. Animal Veterinary Advances, 3 : (4), 208-212.

Chandra, R. (1998), Nuclear Medicine Physics the Basics. $5^{\text {th }}$ ed. New York: Williams and Wilkins.

Chen, W. L.; Perng, M. Y.; Hwei, D. Z. and Yu, M. D. (1994), Therapeutic drug monitoring can avoid iatrogenic alterations caused by ${ }^{99 \mathrm{~m}} \mathrm{Tc}$-methylene diphosphonate (MDP)-gentamicin interaction. $J$. Nucl. Biol. Med., 38 : (4- Suppl. 1), 132-134. 
Cronhjort, M.; Saaf, M.; Sjoberg, H. E.; Schnell, P. O. and Jacobsson, H. (1998), Influence of the phosphate balance on the activiy distribution of $99 \mathrm{mTc}$-hidroxymethylene diphosphonate. Experimental studies in the mouse. Acta Radiol., 39 : (4), 427-433.

Early, P. J. and Sodee, D. B. (1996), Principles and Practice of Nuclear Medicine. Toronto: Mosby-Year Book Inc.

Gomes, M. L.; Braga, A. C. S.; Mattos, D. M. M.; Freitas, R. S.; Boasquevisque, E. M. and BernardoFilho, M. (1998), Mitomycin-C effect on the biodistribution of the radiopharmaceutical techenetium $^{-99 \mathrm{~m}}$-methylenediphosphonic acid in balb/c mice. Nucl. Med. Commun., 19, 1177-1179.

Gomes, M. L.; Mattos, D. M. M.; Freitas, R. S.; Diré, G. F.; Lima, E. A. C.; Souza, S. M. and BernardoFilho, M. (2002), Evaluation of the effect of mitomicin-C on the bioavailability of technetium$99 \mathrm{~m}$ labeled sodium pyrophosphate in mice. Cell. Mol. Biol., 48 : (7), 757-759.

Harbert, J. C.; Eckelman, W. C. and Neumann, R. D. (1996), Nuclear Medicine Diagnosis and Therapy. New York: Thieme Medical Publ.

Hesslewood, S. and Leung, E. (1994), Drugs interactions with radiopharmaceuticals. Eur. J. Nucl. Med., 21, 348-356.

Hladik III, W. B.; Saha, G. B. and Study, K. T. (1987), Essentials of Nuclear Medicine Science. London: Williams and Wilkins.

Hojelse, C.; Kristensen, K. and Sampson, C. B. (1994), Factors which affect the integrity of radiopharmaceuticals. In: Sampson, C. B. (Ed.). Textbook of Radiopharmacy Theory and Practice. London: Williams and Wilkins. pp. 145-151.

Hung, G. L.; James, A. P. and Hammes, R. J. (1996), Radiopharmaceuticals related pitfalls and artifacts. Semin. Nucl. Med., 26, 208-255.

Jales Jr., L. H.; Xavier Holanda, C. M. C.; Ramos, A. M. O.; Jales, R. L. C.; Britto, P. L. J.; Jales, R. D.; Jales- Neto, H.; Viana, L. S. A. A.; Teixeira, M. L.; Catanho, M. T. J.; Leite, R. C. H.; Britto, L. M. L.; Brandão, K. C.; Amorim, L. F. and Bernardo-Filho, M. (2004), Influence of the morphine on the kinetic of biodistribution of technetium-99m labeled with MDP in Wistar rats. J. Animal Veterinary Advances, $3:$ (5), 306-310.

Klayman, D. L. (1985), Qinghaosu (artemisinin): an antimalarial drug from China. Science, 228, 1049-1055.

Mattos, D. M. M.; Gomes, M. L.; Freitas, R. S. and Bernardo-Filho, M. (1999), Effect of the chemotherapeutic drugs on the biodistribution of the raiopharmaceutical ${ }^{99 \mathrm{~m}} \mathrm{Tc}$-phytate in Balb/c mice. In: Nicolini, M. and Mazzi, U. (Eds.). Technetium, Rhenium and Other Metals in Chemistry and Nuclear Medicine. Podova: Servizi Grafici. pp. 465-472.
Meshnick, S. R. and Dobson, M. J. (2001), The history of antimalarial drugs. In: Rosenthal, P. J. (Ed.). Antimalarial chemotherapy. Mechanism of Action, Resistance and New Directions in Drug Discovery. Totowa, New Jersey: Humana. pp. 15-25.

Miller, L. H.; Baruch, D. I.; Marsh, K. and Doumbo, O. K. (2002), The pathogenic basis of malaria. Nature, 415, 673-679.

Owunwanne, A.; Patel, M. and Sadek, S. (1995), The handbook of radiopharmaceuticals. London: Chapman and Hall.

Owunwanne, A.; Shihab-Eldeen, A.; Vacoub, T. and Ziada, G. (1998), The use of radiopharmaceuticals as an effective toxicologic technique for studying nephrotoxicity of drugs: cyclosporine-A. Hum. Exp. Toxicol., 17, 613-619.

Palmer, K. J.; Holliday, S. M. and Brogden, R. N. (1993), Mefloquine - a review of its antimalarial activity, pharmacokinetic properties and therapeutic efficacy. Drugs, 45, 430-75.

Perkins, A. and Frier, M. (1999), Nuclear Medicine Pharmaceutical Research. London: Taylor and Francis.

Price, R. N. C.; Cassar, A.; Brockman, M.; Duraisingh, M.; van Vught, N. J.; White, F. and Krishna, S. (1999), The pfmdrl gene is associated with a multidrug-resistant phenotype in Plasmodium falciparum from the western border of Thailand. Antimicrob. Agents Chemother., 43, 2943-2949.

Schwartz, E.; Potasman, I.; Rotenberg, M.; Almog, S. and Sadetski, S. (2001), Serious adverse events of mefloquine in relation to blood level and gender. Am. J. Trop. Med. Hyg., 65, 189-192.

Sampson, C. B. (1993), Adverse reactions and drug interactions with radiopharmaceuticals. Drug Safety, 8, 280-294.

Sachs, J. and Malaney, P. (2002), The economic and social burden of malaria. Nature, 415 : (7), 650-655.

Saha, G. B. (1998), Fundamentals of Nuclear Pharmacy. New York: Springer-Verlag.

Santos, J. S.; Paula, E. F.; Correa, T. G.; Freitas, L. C.; Fonseca, L. M.; Gutfilen, B. and Bernardo-Filho, M. (1995), Effect of cyclophosphamide on the biding of ${ }^{99} \mathrm{TcO}_{4}^{-}$and ${ }^{99 \mathrm{~m}} \mathrm{Tc}-\mathrm{MDP}$ to blood cells and plasma proteins. Braz. J. Med. Biol. Res., 28, 131-135.

Trhall, J. H. and Ziessman, H. A. (2003), Medicina Nuclear. Rio de Janeiro: Guanabara-Koogan.

van Agtmael; M. A.; Eggelte, T. A. and van Boxtel, C. J. (1999), Artemisinin drugs in the treatment of malaria: from medicinal herb to registered medication. Trends Pharmacol. Sci., 20, 199-204.

White, N. J. (1999), Antimalarial drug resistance and combination chemotherapy. Philos. Trans. R. Soc., 354, 739-749.

White, N. J. and Pongtavorndinya, W. (2003), The de novo selection of drug-resistant malaria parasites. Proc. R. Soc. Lond. Biol. Sci., 2, 67-71. 
White, N. J. (2004), Antimalarial drug resistance. J. Clin. Invest., 113 : (8), 1084-1092.

World Health Organization, Tropical Disease Research Division (2000), TDR News, 62, 1-20.

Xavier Holanda, C. M. C.; Cavalcanti Jales, R. L.; Almeida Catanho, M. T.; Holanda Leite, R.C.; Lopes de Britto, L. M.; Jales Jr., L. H.; Brandão, K. C.; Amorim, L. F, Brito Tiago, G. G.; Gomes, M. L. and Bernardo-Filho, M. (2002), Effects of the glucantime $^{\mathrm{TM}}$ on the kinetic of biodistribution of radiopharmaceuticals in Wistar rats. Cell. Mol. Biol., 48 : (7), 761-765.

Received: July 20, 2005; Revised: November 23, 2005; Accepted: January 24, 2006. 